\title{
Changes in protein profile during coagulation of latex from Carica papaya
}

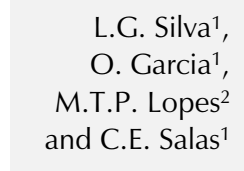

\author{
${ }^{1}$ Departamentos de Bioquímica e Imunologia and \\ ${ }^{2}$ Farmacologia, Instituto de Ciências Biológicas, \\ Universidade Federal de Minas Gerais, \\ 31270-010 Belo Horizonte, MG, Brasil
}

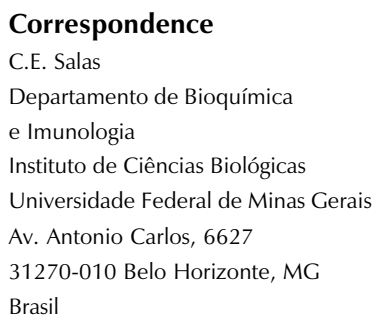

Presented at the XI Annual Meeting of the Federação de Sociedades de Biologia Experimental, Caxambu, MG, Brasil, August 21-24, 1996.

Research supported by FAPEMIG (No. CBS-666/91), PRPQ-UFMG (No. 23072.040751/95-46) and CNPq (Nos. 400190/93-1 and 523304/94-3).

Received April 15, 1996 Accepted February 18, 1997

\begin{abstract}
We describe the changes in peptide composition by SDS-PAGE analysis of latex from Carica papaya collected at various times after incision of the unripe fruit. The data show that during latex coagulation several peptides are processed in an orderly fashion.
\end{abstract}

Key words

- Carica papaya

- Latex

- Endopeptidase

- Cysteine proteinase

- Papain

- Coagulation
A variety of plants contain endopeptidases in their latex as part of their protein constituents. For instance, latex from the unripe fruit of the papaya Carica papaya $\mathrm{L}$. contains a mixture of cysteine endopeptidases, such as papain (EC 3.4.22.2), chymopapains A and B (3.4.22.6), papaya endopeptidase III, papaya endopeptidase IV $(1,2)$ and a recently identified one designated as endopeptidase $\Omega$ (3). Fresh or dried latex obtained from leaves or fruits of Carica papaya following injury contains proteolytic enzymes. The bleeding process goes on for a few minutes until a latex clot forms on the affected area. This defense process strongly resembles blood coagulation and clot formation during wounding in mammals (4). We propose that these two phenomena bear some similarities and that latex proteinases play a role akin to blood coagulation factors endowed with proteolytic activity.

To evaluate the steps involved in clot formation, we analyzed by electrophoresis the spontaneous latex transformations for a period of $20 \mathrm{~min}$, which encompasses the time required to produce a clot. Latex was collected at various times (1-1200 s) following a single wounding of the fruit with a steel razor blade. The samples were collected at $4^{\circ} \mathrm{C}$ in water or $20 \mathrm{mM}$ iodoacetamide (IAA) $(1 / 1, \mathrm{v} / \mathrm{v})$ and immediately stored at $-70^{\circ} \mathrm{C}$ until used. IAA was used to interrupt spontaneous protein processing due to proteinases. Control samples were collected in water to determine the inhibitory effect of IAA. Protein determination was carried out by the Bradford method (5). The samples $(4 \mu \mathrm{g})$ were electrophoresed according to Laemmli (6) for $2 \mathrm{~h}$ at $110 \mathrm{~V}$ and $15 \mathrm{~mA}$ at $8^{\circ} \mathrm{C}$. Methyl methane thiosulfonate (MMS) was added to a final concentration of $2.5 \mathrm{mM}$ before heat denaturation to prevent degradation during electrophoresis. Protein bands were visualized by silver staining as previously described (7). The molecular weight standards were bovine albumin $(66,000)$, lactic dehydrogenase $(36,500)$, carbonic anhydrase $(29,000)$, trypsinogen 
Figure 1 - SDS-PAGE of latex fractions from Carica papaya. Latex was collected in an equal volume of $\mathrm{H}_{2} \mathrm{O}$ or $20 \mathrm{mM}$ iodoacetamide (IAA) at various times following an incision of the unripe fruit and immediately cooled to $-70^{\circ} \mathrm{C}$. Aliquots $(4 \mu \mathrm{g})$ were heatdenatured for $1 \mathrm{~min}$ with or without methyl methane thiosulfonate (MMS) and loaded on each lane of the gel. The run was performed at $8^{\circ} \mathrm{C}$ followed by silver staining. Densitometry was done with stained dried gels. A profile similar to that shown in the figure was obtained in triplicate experiments, each using different latex stocks. The first lane of each gel contains the molecular weight standards. Groups a-d: a, >36.5 kDa; b, 26-38 kDa; c, 22-25 kDa; $d$ $12-18 \mathrm{kDa}$.
$(24,000)$ and $\alpha$-lactalbumin $(14,000)$.

A complex pattern of 5 to 21 bands of different intensities was observed on each lane of the gels (Figure 1). Based on their migration, the bands were grouped into 4 classes (a, b, c, and d). Group a contained the largest peptides $(>36.5 \mathrm{kDa})$, group b consisted of peptides with a size next to the largest ones (26-38 kDa), group c contained peptides of intermediate size $(22-25 \mathrm{kDa})$ and group $\mathrm{d}$ the smallest peptides (12-18 $\mathrm{kDa})$. Samples stored in water showed sim-
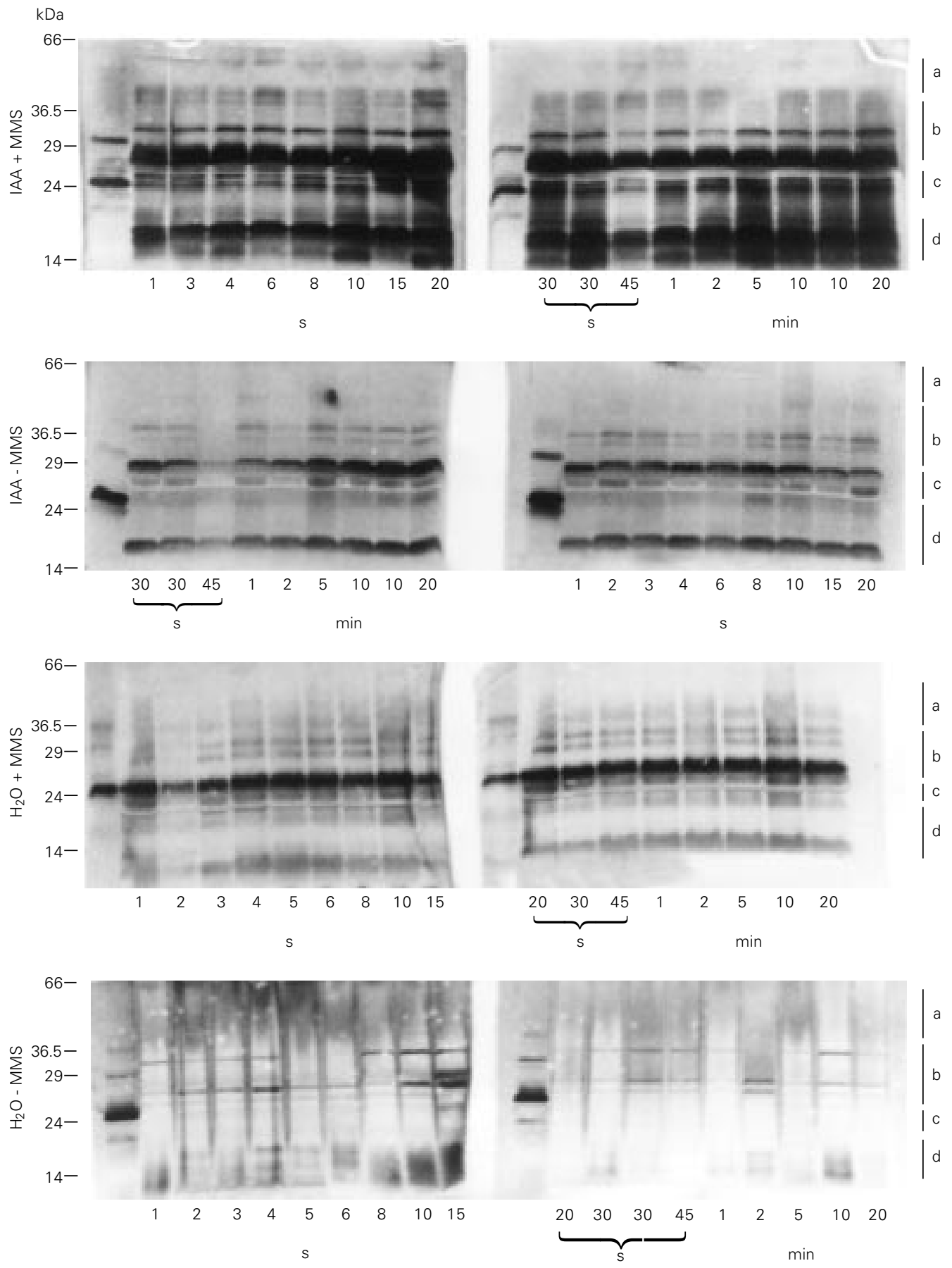
pler profiles than those collected in IAA, suggesting that water permits sample degradation to occur before and/or during electrophoresis. Samples run without MMS showed fewer bands (Figure 1), particularly when they had been collected with water. Under this condition $\left(\mathrm{H}_{2} \mathrm{O}-\mathrm{MMS}\right)$ almost no protein remained in the gel after silver staining. A comparison of latex profiles in Figure 1 shows two major peptide groups, one of 28$26 \mathrm{kDa}$ and the other of 14-17 kDa. Except for latex collected in water and run in sample buffer without MMS, the other electrophoretic conditions preserved this overall profile. We interpret these data to indicate that IAA and/or MMS prevent latex proteolysis during sample handling before electrophoresis and/or during the run. For a comparative analysis of the proportion of each peptide in the mix, we scanned each lane by transmission densitometry at $430 \mathrm{~nm}$ using a Hitachi laser densitometer supplied with CS 9301PC software. Each sample corresponding to the various collection times was run and analyzed on the same day to minimize variations within gels. The intensity of a single band on each lane was related to a standard peptide (internal standard) whose concentration remained constant at the various intervals studied. The relative mass of each peptide in the samples was determined by linear regression analysis of protein standards run together with the samples (Figure 1).

The changes in the relative content of selected peptides during the period (1-1200 s) studied were obtained by plotting the relative areas of each band against the different times at which the samples were collected. The summary of these results is shown in Table 1 . The data obtained for each peptide were fitted into curves by regression analysis using Sigmaplot software and further classified into five categories: I) peptides showing an increase that peaked before 2 min, after a transient drop followed by a decrease and stabilization throughout the remaining period, II) peptides showing a rather continuous decline until attaining a basal level, III) peptides that increased until reaching a plateau, IV) peptides remaining unchanged during the interval, and V) peptides that decreased until they were no longer detected on the gels. The remaining peptides not included in Table 1 displayed random variations in their content that could not be fitted into a curve by regression analysis, and therefore were excluded from further analysis.

In each group, the major profile changes took place between 1 and $120 \mathrm{~s}$, which is about the time when the clot is being formed. This situation led us to assume that these two phenomena are linked. We interpret these results to indicate that a sequential processing of some peptides takes place during clotting, along with the formation of other peptides. The processing profile of peptides in groups Ia and b can be explained by separate trimming steps involving a transiently accumulating peptide. The profile changes of the remaining groups (II-V) can be explained by

Table 1 - Changes in the relative content of some peptides during latex coagulation.

The relative variation of each band was determined by densitometry and analyzed with CS9301PC software (Hitachi) using the less variant peak as standard. The estimated molecular mass $(\mathrm{kDa})$ for each band is shown in parentheses. Samples were collected with iodoacetamide (IAA) or $\mathrm{H}_{2} \mathrm{O}$ and methyl methane thiosulfonate (MMS) was added (+ MMS) or not (- MMS) to the sample buffer. The orientation of the arrow shows the direction of change of relative amount of the peptide.

\begin{tabular}{|c|c|c|c|c|}
\hline Peptide variation & $\mathrm{IAA}+\mathrm{MMS}$ & IAA - MMS & $\mathrm{H}_{2} \mathrm{O}+\mathrm{MMS}$ & $\mathrm{H}_{2} \mathrm{O}-\mathrm{MMS}$ \\
\hline 1) $\searrow \nearrow>\rightarrow$ & $\begin{array}{l}a_{1}(47) ; a_{2}(45) \\
a_{3}(43) ; a_{4}(42) \\
a_{5}(40) ; b_{1}(38) \\
b_{2}(37) ; b_{3}(35) \\
b_{4}(32)\end{array}$ & & & \\
\hline II) $>\rightarrow$ & & & & $\begin{array}{l}a_{3}(43) ; a_{4}(42) \\
b_{4}(33)\end{array}$ \\
\hline III) $\boldsymbol{\lambda} \rightarrow$ & & $\begin{array}{l}d_{1}(18) ; d_{2}+d_{3}(16) \\
c_{1}(24) ; c_{2}(22)\end{array}$ & $a_{2}(52)$ & \\
\hline IV) $\rightarrow$ & & $a_{4}(38)$ & & $\begin{array}{l}b_{5}(28) ; c_{1}(24) \\
c_{2}(22)\end{array}$ \\
\hline V) $>$ & & $a_{1}(54)$ & & \\
\hline
\end{tabular}


simpler processing steps. Preliminary unpublished observations have revealed that proteolytic activity can be detected by in situ SDS-PAGE experiments at early intervals (3-5 s) after fruit incision, followed by progressive increases at later intervals. A qualitative comparison of the amount of enzyme elicited in situ at different intervals suggests that its level must be minimal at zero time, implying that protease activation occurs only after injury (data not shown).

The presence of papain precursors between $39-24 \mathrm{kDa}$ in $C$. papaya was previously demonstrated $(8,9)$. Some of these propapains $(38 \mathrm{kDa})$ are of a size within the range of the protein bands described here. Previous work (8) described an intramolecular mechanism which accounts for the conversion of propapain to papain. However, attempts to produce active papain following in vitro translation of larger precursors were unsuccessful. Based on the preliminary evidence of in situ SDS-PAGE experiments, indicating the sequential activation of at least four distinct proteolytic activities in latex (data not shown), we favor the notion of a processing assisted by other enzymes.

A closer examination of samples collected with IAA and electrophoresed with or without MMS showed that most of the larger peptides in group a were absent in samples run without MMS. In fact, the overall profile for each time in IAA-MMS (Figure 1) shows a significant loss of each of the components. Also, the initial accumulation of peptides $a_{1}{ }^{-}$ $\mathrm{a}_{4}$ seen with MMS (Table 1) was absent when MMS was not added to the SDS-running mix. It was concluded that some processing of samples occurred during electrophoresis. Previous studies (10) revealed that the addition of $2 \%$ SDS and $5 \mathrm{mM}$ DTT to the samples did not prevent significant degradation by the remaining endogenous proteinases during electrophoresis at $8^{\circ} \mathrm{C}$. We therefore suggest that the combination of IAA + MMS blocks further processing of latex, so that the SDS-PAGE profile of these samples reflects the peptide composition at the time of collection.

We cannot rule out the possibility that binding of MMS modifies the migration of peptides containing reacting cysteine residues due to abnormal disulfide bridge formation between enzymes and/or between enzymes and the inhibitor.

Interestingly, some of the peptides produced without MMS $\left(\mathrm{c}_{1}, \mathrm{c}_{2}\right)$ may represent some of the proteolytic activities known to be present in Carica papaya (1-3,11-14). We propose here that some of these proteinases may play an active role during latex coagulation.

It is tempting to establish a parallel between this phenomenon and the blood coagulation cascade evolved by mammals in which a group of serine proteinases is involved (4). The fact that latex proteolytic enzymes are cysteine proteinases does not challenge this notion since cysteine enzymes might be the products of independent evolution.

A quite different defense mechanism occurs in latex from Hevea brasiliensis. A lectin-like protein called "hevein", the major protein of vacuolar structures in the latex of the rubber tree, is involved in the coagulation of latex by polymerizing rubber monomers (15). Interestingly, the C-terminal region of "hevein" shares homology with wound-inducible genes. Wound-inducible genes are part of a systemically induced defense mechanism found in leaves from Lycopersicon esculentum and Solanum tuberosum (16). In this case, genes encoding proteinase inhibitors are expressed in response to leaf wounding. It will be interesting to find out if the expression of woundinducible genes involving proteinase inhibitors occurs in Caricaceae.

\section{Note added in proof}

While this manuscript was being reviewed, we obtained additional evidence of 
the sequential activation involving proteinases in latex from $C$. papaya. In situ measurement using SDS-PAGE of the proteinase activity of latex fractions collected at different times showed the activation of a protein- ase $(22 \mathrm{kDa})$ that peaked between 5 and $60 \mathrm{~s}$. Fractions collected after $60 \mathrm{~s}$ showed a partial reduction of this activity, whereas a larger proteinase became visible after $3 \mathrm{~min}$.

\section{References}

1. Barrett AJ \& Buttle DJ (1985). Names and numbers of papaya proteinases. Biochemical Journal, 228: 527.

2. Ritonja A, Buttle DJ, Rawlings ND, Turk V \& Barrett AJ (1989). Papaya proteinase IV amino acid sequence. FEBS Letters, 258: 109-112.

3. Dubois T, Kleinschmidt T, Schnek AG, Looze $Y$ \& Braunitzer $G$ (1988). The thiol proteinases from the latex of Carica papaya $\mathrm{L}$. The primary structure of proteinase omega. Biological Chemistry HoppeSeyler, 369: 741-754.

4. Furie B \& Furie BC (1988). The molecular base of blood coagulation. Cell, 53: 505518.

5. Bradford MM (1976). A rapid and sensitive method for the quantitation of microgram protein utilizing the principle of protein-dye binding. Analytical Biochemistry, 72: $248-254$

6. Laemmli UK (1970). Protein electrophoresis in slab gels. Nature, 227: 680-683.
7. Schoenle EJ, Adams LD \& Sammons DW (1984). Insulin-induced rapid decrease of a major protein in fat cell plasma membranes. Journal of Biological Chemistry, 259: 12112-12116.

8. Brocklehurst K \& Kierstan MPJ (1973). Propapain and its conversion to papain: a new type of zymogen activation mechanism involving intramolecular thioldisulphide interchange. Nature: New Biology, 242: 167-170.

9. Cohen LW, Fluharty C \& Dihel L (1990). The synthesis of papain in Escherichia coli. Gene, 88: 263-267.

10. Bravo LM, Hermosilla L \& Salas CE (1994). A biochemical comparison between latex from C. candamarcensis and C. papaya. Brazilian Journal of Medical and Biological Research, 27: 2831-2842.

11. Mitchel REJ, Chaiken IM \& Smith EL (1970). The complete amino acid sequence of papain. Journal of Biological Chemistry, 245: 3485-3492.
12. Robinson GW (1975). Isolation and characterization of papaya peptidase A from commercial chymopapain. Biochemistry, 14: 3695-3700.

13. Zucker S, Buttle DJ, Nicklin MJH \& Barrett AJ (1985). The proteolytic activities of chymopapain, papain and papaya peptidase III. Biochimica et Biophysica Acta, 828: 196-204.

14. Dubois $T$, Jacquet $A$, Schnek $A G$ \& Looze $Y$ (1988). The thiol proteinases from the latex of Carica papaya L. Biological Chemistry Hoppe-Seyler, 369: 733-740.

15. Gidrol X, Chrestin H, Tan HL \& Kush A (1994). Hevein, a lectin-like protein from Hevea brasiliensis (rubber-tree) is involved in the coagulation of latex. Journal of Biological Chemistry, 269: 9278-9283.

16. Ryan CA \& An G (1988). Molecular biology of wound-inducible proteinase inhibitors in plants. Plant Cell and Environment 11: 345-349. 